\title{
ICONOGRAPHY OF PLATO IN ANTIQUITY AND IN MEDIEVAL ORTHODOX PAINTING
}

\author{
DANIIL YU. DOROFEEV \\ Saint-Petersburg Mining University, dorofeev_dyu@pers.spmi.ru \\ ROMAN V. SVETLOV \\ Herzen State Pedagogical University (Saint-Petersburg), spatha@mail.ru \\ MiKHAIL I. MiKESHIN \\ Saint-Petersburg Mining University, mikeshin_mi@pers.spmi.ru \\ MARINA A. VASILYEVA \\ Saint-Petersburg Mining University, vasileva_ma2@pers.spmi.ru
}

\begin{abstract}
The article is devoted to the topic of visualization, which is relevant for the modern world in general and scientific knowledge in particular, investigated through the image of Plato in Antiquity and in medieval Orthodox painting. Using the example of Plato's iconography as a visual message, the authors want to show the great potential for the development of the visual history of philosophy, anthropology and culture in general, as well as the new visually oriented semiotics and semantics of the image. This approach reveals expressively and meaningfully its relevance for the study of Plato's image, together with other ancient philosophers' images, in Orthodox medieval churches in Greece, Serbia, Romania, Bulgaria and, of course, ancient Russia in the 15th-17th cc, allowing to see the great ancient Greek philosopher from a new perspective.
\end{abstract}

KEYWORDS: Plato's iconography, Antiquity, medieval Orthodox churches, image aesthetics, visual history of philosophy and culture.

\section{I}

In Roland Barthes' famous 1964 article "The Rhetoric of the Image" (Barthes 1994, 297-319) a structural and semiotic analysis of the visual image is undertaken with the "Panzani" pasta advertisement as an example. A visually perceived image is seen as a message, more accurately, as multiple messages. The first message is linguistic (advertising labels), and it is divided into denotative (literal, direct) and connotative (more deep, additional, symbolic) messages. The second message is iconic with the code, embodied in the visual image and its sign system ("Italianness"). Finally, the third message is analogous (or iconic without code), i. e. the

$\Sigma \mathrm{XO} \Lambda \mathrm{H}$ Vol. 15. 1 (2021) classics.nsu.ru/schole/
(C) D. Dorofeev, R. Svetlov, M. Mikeshin, M. Vasilyeva, 2021 DOI:10.25205/1995-4328-2021-15-1-31-52 
perceived image is seen not as arbitrary, but as an equivalent reproducing (though never copying) of really existing pasta (this message is especially typical of photographic images). Barthes' article is highly informative and interesting for studying the peculiarities of perception of the image and "image structure in its integrity" (Barthes 1994, 302). It is based on a paradigm typical of the works of 196os-1970s French structural philosophers, defined by the fact that in the relationship between the visual (image) and the narrative (language) the absolute priority and defining role belongs to the latter.

A lot has changed since the time the article was written, and this assessment is no longer apparent, since for various reasons (including technological ones) the visual has already got out from the repressive power of the text; for example, the global spread of the web and the ubiquitous adoption of computer technology into our daily lives allows us to talk about the transition from image narrativization to increasing visualization of texts. Indeed, the visual image has largely gained sovereignty and began to define our perception of the world in general and language in particular. Therefore, in our time it is so natural and even necessary to disclose the visual component of the history of philosophy. It appears not as a secondary, subordinate in its meaning to a written text, serving as its illustration, attractive, but not mandatory, but as an independent and fundamental perspective of research, able to re-imagine both philosophy in its development, and a philosopher. Naturally, it means a new understanding of the relationship between the visual and the narrative in the perceived image.

The increasing role of the visual component in modern culture is clearly manifested in some of scientific research on this topic. Today we find a lot of works that consider the image in the context of visual anthropology. The best of them are characterized by a wide theoretical base and interesting material: images of various phenomena, events, brands, places, and so on (Rassadina 2017, 603-6o7; Yelubayeva, Mironov, Kharchenko, Putecheva 2019, 547-562).

Michelangelo suggested that Christianity should appropriate the antiquity past of mankind in order to endow the titanic power of saints and prophets. At the same time, the idea forms a single image that embodies it. One can imagine art as a visible sum of ideas. Including "painting creates parallel texts that can be regarded as invariants of scripture." Its form of dialogue between antiquity and Christian moral issues has been known since the Renaissance. According to the interpretations of scholastics, images are revealed by four methods. The first stage is a literal interpretation of what he saw, the second one is reading of the allegory, the third is the moral interpretation, and the fourth is the metaphysical interpretation of the image (Kantor 2020). This scheme "works" both with visual and mental images. As an example, let us give images from a different area - from 
the modern technological culture. Today, the professional and mass ideas about the resource industry and environmental problems are being discussed. It is these perceptions that collide in the debate about how our society should be organized and what rules it should follow for optimal development. Differences in understanding of the situation arise not only because of disputes "at one level" but also due to different interpretational levels of generalized or familiar images of the situation and participants. Thus, professionals build an ideal image of their industry, based on the detailed analysis, calculations and scientific forecast, persuading themselves and others in solid scientific background and correctness of their opinion (Litvinenko 2020a, 1521-1541; Litvinenko 202ob, 59-91; Tcvetkov, Cherepovitsyn, Makhovikov 2020, 391-402). Occasionally they tend to ignore the important social and humanitarian factors and public reactions, sometimes interpreted as illiterate, politicized, and provoked by the media. However, serious and thoughtful evidentiary approaches often force to reconsider the usual ordinary ideas - in our case, it is the perception of images and characters of ancient thinkers and wisdom in Christianity in general.

We believe that the theoretical significance of the study is not only to "sharpen" or test different approaches to the analysis of visual objects. We are convinced that today there is a number of concepts and phenomena for which the canon of visual representation has not yet been formed. A striking example of such a concept, not being formed, but often used in different discourses, is ecology. Advertising practices of the image of "environmental" products are easy to imagine, however, separating ecology-science from ecology-trend, we come across some emptiness and uncertainty. This ambiguity is caused (and at the same time exacerbates) by the multiplicity and blur of the term itself. Today, we see publications emerge that use the concept of "ecology" in different, opposite, and sometimes unrelated meanings (Bykova, Pashkevich 2020, 135-142; Ponomarenko, Volnik, Marinina 2016, 882-891; Vakhnin 2016, 761-765). Hence we suppose it is important and interesting to view the historic process of specific visual code generation for difficult and ambiguous phenomena which include the idea of wisdom in Orthodox, Christian and European cultures.

It is within the context of visual anthropology and the history of philosophy formation that we dare to approach the vast theme of Plato's iconography in Antiquity and the Middle Ages. In order to make the topic commensurable with the possibilities of one article, the authors limit the Middle Ages to the East Christian Orthodox territory, concentrating on its painting. Of course, we need to keep in mind that the image of pasta differs from the image of a person, and the image of a classic work of art, sculptural or pictorial, differs from a photographic (especially advertising) image. As an example, let us use the characterizing image of the 
three-tiered model of R. Barthes' message to the image of Plato, predominantly plastic (sculpture) in Antiquity and pictorial in the Orthodox Middle Ages.

In Ancient Greek sculptures, busts, herms of philosophers and their Roman copies, the lingual message is poorly represented, for example, as a name allowing to identify the image. However, taking into account mainly oral nature of the ancient culture, people recognized the image not by such a "narrative label" but on the basis of the cultural prevailing of general, often symbolic and ultimate ideas about the appearance of a philosopher in general, a representative of a separate philosophical school and its specific representative, especially the founder or the great one, as well as their characteristic visual attributes (more on this: Dorofeev, Savchuk, Svetlov 2019b). Unsurprisingly, in most of the sculptural works that have come to us (even considering that many of them have been lost in centuries) the name of the depicted famous person is absent (it does not refer to mosaics or even more to frescoed images, in which names are much more common), which creates an interesting problem of identification (Hafner 1984). Another thing is that in medieval Christian culture, when the meaning of the written word has increased significantly and even been sacralized, we often meet an image of a philosopher with a large number of inscriptions from various written sources (more details on the topic below), designed to determine the appraisal perspective of the image perception and allowing to identify the image. It was facilitated by the fact that in Orthodoxy the iconography of ancient philosophers and in particular Plato was presented mainly in the form of fresco painting or, say, in the form of images on church metal or copper gates (as in the Annunciation Cathedral of the Moscow Kremlin or the Trinity Cathedral of the Ipatiev Monastery) - in both cases, it was easy to present the text, as opposed to a sculptural image.

The second message, an iconic one with a code, in Antiquity showed up primarily as a visual component of the image, not textual. For example, an integral part of Pythagoras's plastic image was his turban which both testified of his journey to the East, and symbolized his wisdom in a more distant way. Such visual indications or references to certain meanings were quite sufficient to an educated Greek or Roman due to the continuity and effectiveness of the cultural tradition, which in the Christian Middle Ages is already beginning to be interrupted and changed by introduction of new, actually Christian reminiscences and connotations, which are largely supposed to be written sources, because of which the visual image of a philosopher, Plato for instance, could be modeled in many ways. It is necessary to add a large number of legends about the philosopher. Being visualized, they became a part of his iconography, in Russia as well. For example, it happened to a story of finding in a coffin and baptising of Plato's bones during 
Emperor Constantine and his mother Irina (about the legends associated with Plato: Chizhevsky 1930, 71-74).

All these factors directly influence the character of the third message in the perceived image, namely, the analogous, iconic message without code. Being in front of a sculptural image of a thinker, a Greek or Roman could identify his personality not by referring to his real prototype (photos were not yet invented), be it Plato or Aristotle, but through common semantic-visual schemes and models developed in ancient, predominantly Ancient Greek culture in relation to the image of a philosopher. In this regard, the iconography of Roman copies of Greek philosophers is determined by the ultimate ideas about them and subordinates them to the features of the real appearance of a particular person. As well it fundamentally differs from the iconography of the Roman portrait, characterized, as it is known, by individual naturalism (Voschinina 1974). By the way, the Orthodox tradition defines the pictorial image of a man, a saint or an ancient philosopher by a special normative written corpus, the so-called iconic original which gave clear rules of picturing of both the image and the text following it, which we meet in Erminii of Dionys Fournagrafiot of the 18th-century Athos painter who summarized and preserved for us the medieval Orthodox traditions in that area (however, the iconic originals were different and could, although not drastically, differ in the rules and content of the accompanying image of the inscription - for example, we know Strogonovsky iconic original which served as an original for Strogonov school iconographers: Byslayev 1861, 360-365). Here is how he prescribes to depict Plato in the 135th section of his work, which presents iconographic norms for other ancient philosophers who predicted the incarnation of Christ: "An old man with a long wide beard says: "Old with his days is young, and young is eternal. Father in Son and Son in Father. The single is triple, and the triple is one." Here is the norm for Plato's depiction in the 16th-century "Collected Facial Original" indicating not only what the philosopher's appearance should be, but also specifying what should be written in his scroll (which suggests that the text was understood as an integral part of the image): "Blond, curly. In the crown; robe is blue, underside is cinnabar; hand points to the scroll. It says. As he is good, he is blessed, but not malicious ones. It also says: Apollo is not a god, but there is the god in heaven; he is to come down to the earth and to be incarnated from the pure virgin, in him I believe; and four hundred years after his divine birth the sun will shine on my bones" (quoted by: Kazakova 1961, 366). These rules do not show the real appearance of the philosopher, but the way he was understood in a certain historical-cultural, axiological, and religious context. It correlates rather with the ideal pre-image built in a particular era and with certain, often reimagined, sources. Plato could be depicted very young, as in the frescoes of St. Nicholas 
Church in Yanina and in the refectory of Bachkov monastery, or, more often, as a wise experienced old man, also Russified in his appearance and clothing (as in Novospasskiy monastery in Moscow) or in an eastern appearance with a turban on his head (like in the Iviron monastery of Athos). Art in general is difficult to understand as an imitation or a reproduction of reality, and even photography, seemingly visually embodying this function, in fact never copies reality but creatively reflects, transforms, or models it (on which advertising is based). In the medieval Orthodox tradition, the images of ancient philosophers are much fewer embodying traces of the real appearance of their heroes as in Antiquity. A more or less educated person, brought up in this tradition and fed by it, easily recognized particular thinkers in them. Among other reasons, it was carried out because the perceived pictorial image was always represented in the context of meaning (which was different from the plastic, sculptural image, because Antiquity did not depict philosophers in the plot composition, like the Laocoön Group, or even in a group), being correlated with other images, people and symbolic objects, as well as with accompanying inscriptions.

Such reflections are extremely interesting and relevant in the field of visual semantics and semiotics, and we cannot ignore them. However, our topic is also interesting and significant as is, touching on the current problems of modern philosophy, such as the aesthetics of a human image, visual anthropology, the meaning and features of the ratio of visual and narrative in the perceived image, etc. And, of course, these studies should give a strong impetus to the history of philosophy, revealing its visual personalistic component. After all, the iconography of ancient philosophers, including Plato, is not just a beautiful appendage to their teachings, it is a visible embodiment of (self)understanding of philosophy and a philosopher in a particular historical and cultural period; in fact, it is a specific result of visual-meaning dialogue of cultures, traditions, and ideological attitudes. It is impossible, especially in our time of visualization of culture and all everyday life, to ignore it, to move away from the fundamental study of the problem of image, reducing it to illustrative materials. It is even stranger that such a famous researcher of Plato as Luc Brisson in his generalizing book about Plato did not give a chapter to Plato's iconographic image (Brisson 2017). If the iconography of Aristotle in the Russian scientific literature was studied by V. P. Zubov (Zubov 1963, 319-332), the image of the Stagirite's great teacher does not still have a worthy independent study. Therefore, taking the first step in this direction, we will now dwell on the features of Plato's iconography in Antiquity and in the Orthodox Middle Ages. 
The ancient images of Plato do not seem to carry the physiognomic and, at the same time, philosophical mystery of the mismatch between the inner and outer man, which we see on the example of the appearance of Socrates (Svetlov 2012, 16-28; Svetlov 2015, 169-184 ). However, we can make some inquisitive observations.

First of all, it is worth noting that literary descriptions of Plato's appearance have come to us from quite late times. Epictetus describes him as "beautiful and strong". Plutarch speaks of his slouch, which was supposedly imitated by some fans of his wisdom. Simplicius defines him as endowed with beautiful eyes. It probably means "with good vision" (maybe Simplicius speaks of Plato's specific kind of vision, namely, speculation).

Diogenes Laërtius hints of Plato's appearance primarily related to the origin of his nickname (Platon is a nickname from the adjective platýs meaning "broad"), which became his philosophical name (Diog. Laërtius. De vita. III. 5).

If we talk about the ancient iconography of Plato, we see, in fact, two variants of his portrait: first, an elderly, brooding man. According to the common opinion of modern historians, his herm was mounted in the Academy in the 340s, shortly after philosopher's death. The Roman copies that came to us were made from this herm. Its "replicas" can be found, for example, in Berlin Altes Museum, in the Museum of Pergamon, in the Louvre, in the Vatican Museum (in the latter case on the bust/herm "Zenon" is mistakenly written). The image may convey the real appearance of the thinker good enough. Especially if we think about the words of Amphia, the comedian cited by Diogenes:

"Ah, Plato, Plato,

After all, you only know how to be sullen

And with eyebrows bent like snails" (Diog. Laërtius. De vita. III. 27).

Perhaps Diogenes had that herm in mind when he wrote: "And Persian Mithridates (as reported in the First book of Favorinus' "Notes") erected a statue of Plato in the Academy, with the inscription: "Mithridate Persian, son of Rhodobat, devotes to Muses this image of Plato, the work of Silanione"'” (Diog. Laërtius. De vita. III. 25). Of course, this testimony is one of historical mysteries. If Mithridates, the son of Rhodobat, was the satrap of Cappadocia who died around $362 \mathrm{BC}$, then the event should have happened during Plato's lifetime. However, there is a problem with Silanion. Pliny the Elder claims that the acme of this Athenian sculptor belonged to the 113th Olympiad, i.e. 328-325 BC. Therefore, he could not create the herm in the 36 os. Perhaps it was some other Mithridates, and the statue was created for the Academy after Plato's death. 
There is the second "type" of images where Plato looks like an athlete (for example, in the Capitol Museum). If these images are not a late forgery, they convey not real Plato's appearance, but what it might be, in connection with his nickname "Broad" and the information about his wrestling activities.

However, Diogenes Laërtius quotes historian Timothy that Plato had a weak voice (Diog. Laërtius. De vita. III, 5). It is indicated not in the context of his physical health and, accordingly, appearance, but in the context of young Plato's poetic creativity. Indeed, an ancient poet is necessarily a reciter. It was a tradition and, it seems to us, was only increased by not too actively developed skills of reading "to oneself" (we will leave aside the "big dispute" about how people read in Ancient Greece and Rome, but note that "reading out loud" was quite developed in any case). Thus, a poet, as well as a public speaker, needed to have a strong voice and a clear diction (compare the story of Demosthenes' "training").

The weakness of Plato's voice seems to contradict that version of the origin of his name/nickname "Broad" which is associated with his sports (Diogenes Laërtius recalls three versions: the breadth of his speech, the breadth of his forehead — quite a physiognomic trait — and the strength of his body formed by wrestling). However, relatively recently Stephen Miller published a book (Miller 2009) in which he addressed to the herm with the inscription "Platon" stored at Hearst Gymnasium for Women, University of California, Berkeley. This herm was previously considered a fake. As an archaeologist, he examined it and came to the conclusion that it is no fake, but an artifact of the Roman era, with several interesting features. On the one hand, the depicted image resembles other ancient portraits of Plato, but this time the head of the philosopher is crowned with a special ribbon $(\tau \alpha i v i \alpha)$, with which ancient Greeks decorated themselves during religious holidays (compare: Pl. Symp. 212d-e). The same ribbons were a frequent element of hairstyles of gods. In any case, the ribbon indicates a special position of the depicted on the herm (tiaras that adorned the kings are similar to such ribbons). The second feature of the herm is even more important. Plato's ears are not symmetrical. The left one is clearly damaged; it is bigger than the right one (S. Miller assumed puffiness). It indicates that herm portrays a professional wrestler or boxer. The author of the monograph, recalling the words of Diogenes Laërtius, suggested that Plato was an athlete indeed. His reasoning in the dialogues about the importance of gymnastic education is not an idle speculation of an "armchair thinker" but a reflection of his own experience. S. Miller suggested that the ribbon-topped Plato was presented as a gymnasiarch, the head of an athletic school. And maybe the Academy included one for a while.

The latter assumption is bold enough, though not impossible. Reid Heather in her article (Reid Heather 2016, 171-186) showed that for Plato's educational para- 
digm body training is an important element of soul education. On the place of physical training in Plato's educational projects, see another article by the same author (Reid Heather 2017, 260-271). And in "Laws", we add, Plato insists that athletic exercises are not "sport for the sake of sport", but prepare the citizens of Magnesia to fulfill their military duty (Pl. Leg. 828d ff.). Boxing and pankration could well be elements of such preparation.

It seems to us that reading the semantics of the visual image of Plato, as interpreted in antiquity, includes taking into account another factor. Socrates' selfdescription in Plato and Xenophon constantly emphasizes the unusual appearance of their teacher, as well as Alcibiades' words about him in "Symposium". But Plato fundamentally removes himself from the texts of dialogues, he is an invisible author. Perhaps this invisibility is connected with his attitude to the traditional "kalokagathos" appearance, which after Socrates's case lost all its significance. It does not matter whether the philosopher is handsome. The beauty of the soul is much more important. Socratic inconsistency between external and internal is a clear argument for such a position. The same position is developed by stoics (see their doctrine of the indifferent). Perhaps, that is why Plato offers us his own invisibility. He even makes his soul invisible, because all the ideas in the dialogues are expressed not by him but by other characters ("Letters", the authenticity of which are actively discussed by modern researchers, we intentionally leave aside). He stresses that he does not look like Socrates. As for Theaetetus, he really resembles Socrates, that is why he is called beautiful and good (Pl. Theaet. 142b).

Plato is only present at the trial, offering himself as a guarantor for Socrates to pay the fine (Pl. Apol. 38b). He did not hear the last words of the Master ("Phaedo" dialogue), but only conveyed from the words of others. We believe that from a dramatic point of view Plato consciously and consistently takes the position of a witness. Yes, all of us understand how often Socrates is the mouthpiece of Plato's ideas. But from the viewpoint of an artistic strategy, as well as the principle of positioning himself in the space of philosophical events unfolding in the pages of dialogue, Plato does not leave the position of an impartial and thoughtful witness, who is invisible, although everything in the dialogues is him, his subjectivity, hence the non-image-ness, non-self-portrait-ness of his texts arises.

Apparently, one should "read" his images from this point of view. The image of Plato-athlete does not contradict the fact that our philosopher was primarily figurative to the internal cause, to the philosophical search, which he was ready to share only with those whom he trusted. No wonder Diogenes Laërtius says that "His desire was to leave memory about himself in friends or in books. For the most part he shunned people, as reported by some" (Diog. Laërtius. De vita. III. 
40). It is probably this "shelter among friends" is shown to us by the famous mosaic from Pompeii depicting Plato's Academy.

III

If the cosmological plastic anthropology of Antiquity is embodied in the sculptural image of a man in general and a philosopher in particular, then, accordingly, Christianity brings and develops personal visual anthropology with a new image of a man, expressed primarily in the icon, but also in the fresco and mosaic painting (more details on Ancient Greek anthropology and significance for it Plato: Dorofeev 2019a, 251-268). However, in the first place in Plato's philosophy Ancient Greece passed to Byzantium the inclination to recognize the ontological status of contemplation and contemplated image (the sensually-visually contemplated and the mystically-speculatively contemplated), the meaning of which was revealed in the new Orthodox theology and art (Festugiere 2009, 16-84, 211-371; Spidlik 2013, 185-242). Iconophilia in Byzantium is primarily associated with the names of John of Damascus and Theodore the Studite. Their images and works were also widely distributed in Byzantine tradition (Goncharko 2017, 291-308; Goncharko 2019, 163-177). Naturally, it influenced not only the iconic image formation, but also the development of visual images of ancient philosophers in fresco painting. That is why Plato's role here was central. We are interested here in, so to speak, "Orthodox Plato".

We would like to see how the image of an ancient philosopher, and above all Plato, appears in this visual personal anthropology, not just in Christian, but in Orthodox painting (the difference of the ancient philosopher's image in Eastern Christian and West Christian painting is a separate vast topic, we do not touch it here). Moreover, the topic remains totally unexplored in the Russian science. What to say about other authors, if even L.A. Ouspensky devotes only a few paragraphs in his book (probably still representing the deepest and most detailed study of Orthodox painting) to the theme of iconography of ancient philosophers in Orthodox churches, generally assessing the phenomenon negatively (Uspensky 2008, 280-281, 432-433). Even Europe has only a few long-time and hard-to-find books on the topic. For example, an old study of A. Premerstein (Premerstein

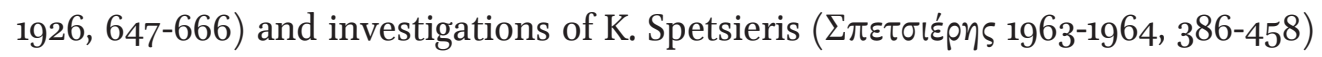
are mainly devoted to the images of ancient philosophers in Greek churches, and the monumental work of I. Duichev (Duichev 1978) studies the image of Antiquity thinkers in ancient Bulgarian painting. For us it is not a narrow historical and artistic research, but a study uniting aesthetics, visual and philosophical anthropology, the history of philosophy, Orthodoxy, but also, of course, art. 
The Orthodox medieval world is large and heterogeneous. Of course, the fundamental iconographic "trend" was set by Constantinople, the capital of the Byzantine Empire up to the fall under Turkish pressure in 1453. But, surely, we need to acknowledge both the self-sufficient value and the authenticity in the matter of Bulgaria, Serbia, Moldova and, of course, ancient Russia. All these countries possess unique collections of images of antique philosophers, especially in temple fresco painting. Although these collections may include different antique philosophers, but in almost every one of them, be it the churches of Athos, Yanina, the Grand Meteoron, the Southern Bukovina, Prizren, Moscow, Novgorod, Kostroma, etc., we will find the image of Plato, a true symbol of Ancient Greek wisdom, especially for Orthodox Christianity.

But first let us clarify a question that can cause embarrassment. More than once we have come across the fact that many people are unaware that in Christian temples there are images of ancient, i.e. formally pagan, philosophers. (But even those who know about it have little idea how this fundamental and littlestudied great tradition, with its principles, the image rules and signs affects the history of philosophy, Christianity, art, all medieval Orthodox culture from the unexpected side!) So, we make a few clarifications. Firstly, temples present not only images of saints, but also, for example, rulers (there are especially many of them in Annunciation, Archangel and Assumption Cathedrals in the Kremlin, close to the royal court) or even just patrons and customers (ktetors and donors). Secondly, monumental painting (mosaic and frescoes) fundamentally differs from the icons in the following: (a) the latter actively and meaningfully participate in services (for example, they are brought to the Cross procession, they are used for blessing, etc.), their sacred status is higher, because they, unlike frescoes or mosaic panels, can be miraculous, directly miraculously manifested by the Virgin or saints; (b) icons are located at the level necessary for a person to pray in personal visual communication, face-to-face, but wall images of frescoes and mosaics can be arranged in such a way (e.g. in the dome, in certain corners inconvenient to perceive) to be difficult to see; (c) wall painting represents a very large, sometimes dozens, if not hundreds, of square meters of the composition, not caught by a single holistic view, as opposed to the icon. It explains why images of ancient philosophers are exceedingly rare on icon boards, but mostly in fresco painting, because they have not so much prayer, as didactic and illustrative value. People pray to the saints, whose distinctive attribute is the light halo, and from the philosophers they learn. However, as we shall see further, there are surprising exceptions; for example, the Oten Poustinia had an icon of 1462, on which Plato is located under John the Theologian and holds a charter with the inscription: "Apollo is not God, but there is a God in heaven, He will come down to earth and 
incarnate" (Shakhmatov 1930, 64). Thirdly and finally, most of the images of philosophers are presented not in the main premises of the church, where the ordinances are performed, but in the preparatory, for example, on the walls of the refectory and porches. Although there are striking exceptions: in the Trinity Church of the beginning of the 18th century in Ostankino (Moscow) the lowest row of the altar, the most sacred place in the Christian temple (closed up to most recently), consisted of images of ancient characters - Apollo, Istoik, Philodos, and Orpheus. By the way, the prophetic saying that accompanies here the image of Orpheus ("Christ will be born by the Virgin Mary, I believe in him...") in other places is associated with Plato, both in the Russian iconographic tradition, and in Romanian, in South Bukovina, in the mural of 1547 with the image of Plato in Voronet. A Russian researcher finds parallel to this saying in Maxim Greek essay, and, perhaps mistakenly, transferred the attribute of Plato's iconography to Orpheus (Sergeyev 1985, 327-328).

Of course, the theme of ancient philosophers' iconography in the Orthodox church should be considered within the dialogue between antiquity and Christianity. These relations were not easy, and we will mention only a few points important for our topic. Justin Martyr, also called a "Philosopher," was the first in the 2nd century who brought the great Greek philosophy and Christianity closer together, showing the semantic kinship of their teachings in some cases. It has also received an iconographic expression. Let us take the mural in the porch of the Grand Meteoron temple: pay attention to Christ over the philosophers. A saint stands on the left and right to the temple door, at the beginning of each row of philosophers; Paul on the left (his words "For since the creation of the world, they have seen the unseen things of God. From the things He made, they can tell that He has everlasting power and is God. Therefore, they have no excuse," Rome 1:20, opened the possibility of joining the true God before the birth of Christ, i.e. in pagan times), Saint Justin Martyr on the right. It was Justin, apparently relying on Diogenes Laërtius (III, 6), who sought to legitimize Plato for Christianity and remarked in his Apologia that the Greek philosopher had taken all his true teachings from Moses, although he did not understand everything in it. Unsurprisingly, according to some Greek researchers, the first "Christian" images of Plato were already created in the 2nd century in the circle of the Gnostic sect of Carpocratians, who recognized both Christ and ancient thinkers. The legend of Plato's journey to the Jews was stable, it was adhered to by such prominent representatives as Clement of Alexandria; as a result, the philosopher even began to be called "Athenian Moses" in literature. Much of it was done by the Alexandria School of Theology (Plato was particularly important for it), which sought to bring the Old and New Testament and Plato's philosophy as close as possible; it is 
not surprising that we meet images of Plato together with Philo of Alexandria more than once.

Legends of Plato had a strong influence on the formation of the visual image of the philosopher in Christianity. One of the oldest sources of iconography of ancient philosophers is the text composed in the 6th century, in which seven wise men (including Plato) gathered in Athens to prophesy about the future of the world. Unsurprisingly, the inscription about this event is placed in the frescoes of the Church of St. Nicholas (156o), called Philantropinon, in Greek Ioannina. The inscription was intended to explain and justify the presence of ancient philosophers' images in the temple. The theme of the prophecy here is the key. It can be explained, as the ancient thinkers were considered as prophets of Christianity comparable with the great Old Testament prophets who predicted the birth of Christ, and it gave them greater legitimacy. Therefore, in this regard it is no coincidence that ancient philosophers began to be depicted mostly together with ancient Sibyls, whose pagan prophetic function developed naturally in relation to Christianity. Thus, the already mentioned Erminii of Dionys Fournagrafiot names the Sibyl, along with the ancient philosophers, among the figures, the images of which should be represented on the walls of the porch, because she predicted the Epiphany and the Last Judgment. Suffice it to say that in the second half of the 17th century, the time of the greatest expansion of ancient images in Russian Orthodox churches, sibyls appear, according to A.N. Muraviev's apt remark, as "a favorite decoration of the times of Alexei Mikhailovich" (Muravyev 1990, 215), so often one could meet them. However, in Russian churches picturesque images of sibyls together with ancient philosophers appeared later than in the West and in other Orthodox countries. The images of Plato, Plutarch and the sibyl in the exonartex of the Church of the Holy Virgin of Ljevis in Prizren (1307-1313) (Djuric 2006, 274-289) or St. Achilles Church in Arill (Okunev 1936, 221-258) are of particular interest in this regard.

Of course, the process of integrating the great ancient philosophers into the space of Christian culture was not easy and various both in different periods and in different regions of the Orthodox world. But still the image of a philosopher in a temple was no longer something out of the ordinary, because in the 12th century, in addition to Byzantine churches, images of Plato existed in the Church of the Holy Cross in Jerusalem and in the Church of the Nativity in Bethlehem. In ancient Russian culture the attitude to Plato was even more heterogeneous given the heterogeneity and uncertainty of the philosophy itself (a modern researcher singles out as many as 20 models of philosophy understanding in medieval Russia, see: Gromov 2010, 4-31). Suffice it to say that for centuries we have seen both harsh accusations of Plato, identifying him as a heretic, and even the use of al- 
most obscene expressions towards him, as well as positive assessments of the philosopher that recognize the truth of his teachings, largely close to Christianity (Shakhmatov 1930, 49-70). But still the rapprochement of great cultures took place on this reason. It was very revealing and significant, as having been carried out through the visual embodiment, as a kind of visual dialogue, represented by iconographic images in Orthodox churches - the space of communication between man and God. The "churching" of pagan wisdom was intended to show, in particular, that prophecies about Christ characterize not only the Old Testament, but also the antique sages; it corresponded to the tendency towards humanization and "Europeanization" of ancient Russia in the 16th and especially in the 17th centuries. This line was supported by the fact that it was necessary to strengthen the authority and inviolability of the main Christian dogmas in the face of the Heresy of the Judaizers (especially active in Novgorod region) by means of "correct" prophecies of the antique authorities regarding the nature of Christ and the Trinity.

Unsurprisingly, in Russia the iconography of ancient philosophers became widespread primarily due to the 1512 publication of "Prophecies of Hellenic sages" in the "Chronograph" - a collection of texts translated mainly from Greek, in which thirteen ancient characters (which included philosophers, ancient gods, and three Persian Magi) first of all divined of the birth of Christ and the understanding of God as the Trinity. We know at least seven handwritten copies, i. e. editions of the text in the 16 th $-17^{\text {th }}$ centuries (including the copy of the famous book writer Guriy Tushin), which indicates its popularity, influence and even state support, without which the "Kyrill's Book" would not appear, as it was printed by the tzar's order and with the blessing of the patriarch. In different copies of "Prophecies" the number of philosophers and texts of their sayings are changed, but they always include Plato and Aristotle. For example, in St. Nicolas Church of the Vyazhitsky monastery Plato's scroll includes words: "Apollo is not God, but there is God in heavens, he will come down to earth and incarnate." In the "Tushin copy" the same words are attributed to Aristotle. In the second edition of "Prophecies" Plato narrates: "I say, I am sinful, I do not refuse this, but not one before me believed in Christ who went down to hell" (Kazakova 1961, 358-368).

Note that in this text the ancient sages - including ancient gods, most often Apollo, Zeus, in the Slavic translation "Diy", Hermes and Dionysus; Sibyls; poets Homer, Orpheus, Euripides, Menander and Virgil; historians Thucydides and Plutarch; philosophers as such, almost exclusively ancient Greeks - are represented as predicting in their given sayings the birth of Christ and the basic Christian provisions and dogmas, as well as general ethical principles. In Russia, the iconographic tradition based on this text begins, apparently, with the Annunciation 
Cathedral in the Moscow Kremlin, i.e. in the first half of the 16th century (although Shakhmatov's reference to the icon with Plato in 1462 shows that this tradition existed even earlier), and its heyday falls to the 17th century with echoes in the early 18th century. In the Annunciation Cathedral Fyodor Eliseev's frescoes were finished in 1520 , but the fire of 1547 burned them. Apparently, they were completely restored. We can name more frescoes in the gallery of the Novospassky Monastery in Moscow by Fyodor Zubov; those of the Khutyn Monastery Cathedral, murals of St. Nicholas Church of the Vyazhitsky Monastery and a number of others.

We should give a note about inscriptions accompanying visual images of the ancient philosophers and Sibyls, designed to indicate their prophetic status and thus legitimize their appearance in the church: those inscriptions could be different from one church to another, and from one Orthodox country to another. For example, take the Cathedral of the Annunciation in the Moscow Kremlin, in which, most likely, these images first appeared in Russia. In the first third of the 19th century one could clearly see the fresco image of twelve ancient philosophers on the cathedral's porch (Aristotle, Anacharsis, Menander, Plutarch, Sibyl, Anaxagoras, Zenon, Thucydides, Ptolemy, Trismegistus, Socrates and Plato) together with six Old Testament prophets. Such a neighborhood further emphasized that not only Judea had prophecies about the Messiah, but also ancient Greece, "among the pagan peoples, sometimes the reflection of this non-evening light shone in men who, ignorant of the law, did what was lawful by nature" (Muravyov 1990, 236). Naturally, the number of philosophers depicted is not accidental either; it referred to twelve disciples of Christ, philosophers appear here as disciples of the God-man even before the birth of the Savior, prophesied about his coming from pagan darkness. No surprise we often see such a number of images together (although the choice of specific personalities may vary a bit), as evidenced by the refectory laurels of St. Athanasius on Athos (1512), Bachkov Monastery (1621-1623) or Serbian Church in Orillia (1295-1296). Each of these twelve images holds a charter with prophetic sayings (Thucydides' and Ptolemy's statements were absent as early as the 19th century), in which, for example, Aristotle foreshadows the Holy Trinity ("the first is God, then the Word, and the Spirit with them one"), and Plato foretells the Incarnation ("one must hope that God himself will send a heavenly teacher and mentor to people") (Muravyov 1990, 237-238). By the way, the same inscription was on Plato's charter, depicted on the doors of the Assumption Cathedral in Novgorod, and Shakmatov considers it a copy of a more ancient icon, with the inscription corrected and updated (Shakmatov 1930, 65). However, it is worth noting that many sayings are not specifically religious, Christian, but so to speak moral, performing a didactic function. For example, 
Anacharsis denounces despondency as human harm; Plutarch calls us to be afraid of God, to obey parents, to honor priests and elders; Socrates, in full accordance with the spirit of his philosophy, speaks of the immortality of the soul, that no evil will overtake a good person who will receive a reward after death. It is also worth paying attention to the fact that the image in the Annunciation Cathedral, which in the 19th century was probably interpreted as the image of Trismegistus, is now identified as the image of Virgil, whose phrase from the fourth eclogue has long been considered in Western Christianity as a prophecy about the birth of the Messiah. Unfortunately, the Annunciation Cathedral frescoes have reached us in a very bad condition, images of many philosophers are difficult to make out, the best preserved, perhaps, is the image of Virgil, it is still possible see the outlines of Aristotle, Sibyl, Thucydides and Plutarch. It is interesting that back in the 1970s V.N. Sergeyev discovered images of Virgil (exceptionally rare in Russia, perhaps only in the Annunciation Cathedral of the Kremlin) and Diy (Zeus) in the wooden church in Karelian Seltso village in Udomela district of Kalininsky region, and the inscriptions there do not correspond to any of the numerous texts of the "Prophecies of Hellenic Sages" (now in Andrey Rublev Museum in Moscow) (Sergeyev 1985, 328-330).

Also, the appearance and spreading of images of ancient philosophers in Christian temples was strongly influenced by the image of the Tree of Jesse (sometimes called the Root and Vine of Jesse), depicting the ancestry of Christ and also visually embodying the theme of prophecy, based on the biblical text ("And there shall come forth a shoot out of the stock of Jesse, and a branch out of his roots shall bear fruit," Is. 11:1). The first images of the Tree of Jesse appeared in the 9th -1oth centuries in Western Europe, and in the 12th century in the East (Bethlehem, the mosaic of the Church of the Nativity), and the image's heyday

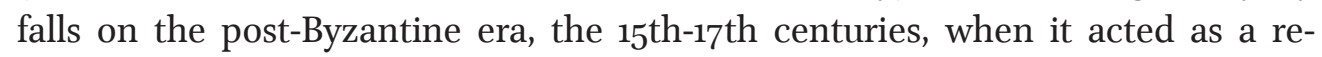
sponse to the Turks expansion and maintained Orthodox traditions, emphasizing the closeness of Greek philosophy to Orthodox Christianity (during the Turkish conquest the Greeks founded "secret schools" in the church porches decorated with images of philosophers). Unsurprisingly, images of ancient philosophers emerged in Western Europe earlier than in the East (including Sibyl, poets such as Homer, Menander and Virgil, historians, first of all, Thucydides and Plutarch), because the Tree of Jesse represents all those who in one way or another points to Christ, thus being associated with Him even before the birth of the Savior. Let's take the IX fresco painting of St. Athanasius Lavra on Athos as an example. Philosophers are traditionally depicted in a refectory; in the center, apparently, the righteous Isaiah or Jesse sleeps, and from him in trunks philosophers depart leading to Christ. 
There were also special iconographic components, representing an interesting visualization of legends. To consider them we move on to the unique complexes of monasteries in South Bukovina, which in the $17^{\text {th }}-18$ th centuries was a part of Moldova and now is a part of Romania. Note that St. Paisius Velichkovskiy lived in Moldova for a long time. He was in many ways the founder of the tradition of the Russian elderness, a translator, a collector, and the publisher of Philokalia at the end of the 18th century. The immediately striking uniqueness of these fresco images is revealed in in their location not on the inner, but on the outer walls of churches. The monasteries of Sucevita, Voronet and Moldovita are particularly interesting for us.

Let us stop only at Sucevita and immediately pay attention to the most interesting image: Plato is depicted with a coffin on his head, decorated with a crown, and there is a skeleton inside the coffin. It has its own story. According to the legend, preserved by Theophanes the Confessor in the "Chronograph" in the 9th century, the coffin of an unknown Hellenic philosopher was found in Thrace, and a plaque was nailed to it with an inscription prophetically predicting the birth of Christ from the immaculate maiden, and the opening of the coffin during the Byzantine emperor Constantine and his mother Irina. It is important for us that the coffin with a skeleton is a symbol of death, but death in Christianity is the beginning of a renewed life. The iconography of Plato with a coffin is an attribute of Romanian Orthodox painting. We still find it, for example, in the monastery of Moldovita, where Plato is depicted in a crown and with a coffin near sibyl, and in Voronet (about the middle of the 16th century).

This iconographic tradition continued in Russia. The legend is represented by the message in the Book of Degrees of the Royal Genealogy compiled during Ivan the Terrible. The Book reported the baptism of those bones and thus the resurrection of the formally pagan philosopher "in Christ"; besides, it quoted the words purportedly of Plato that "Apollo is not a god, but a priest; there is God in heaven, he is the one to come to earth, and to be incarnated from the Pure Virgin, in him I believe." The baptism of the philosopher's bones was considered in the context of the baptism of the remnants of brothers Princes Vladimir Yaropolk and Oleg Sviatoslavich and Christ's descent into hell for the sake of the salvation and resurrection of sinners (the full text is given in: Miroshnichenko 2012, 132-133). The image of "coffined" Plato, on which the rays of the Spirit descend, can be found on the right sash of the southern gilded doors in the Trinity Cathedral of the Ipatiev Monastery. They were Boris Godunov's contribution in 1559 modeled on the doors of the Annunciation Cathedral of the Moscow Kremlin. The philosopher is depicted there next to Apollo, and it is no accident, because Diogenes Laërtius called Apollo "Plato's father" (III, 2), and the Christian iconographic image in- 
cluded an inscription in which he recognizes that God is not Apollo, but Christ. In the lower row of the right sash, we see Sibyl standing in front of Christ. Her image is found on the left sash of the same doors, also in the lower row. The same cathedral of the Ipatiev Monastery was initiated in 1330 by Tatar Murza Chet (baptized as Zacharius), the founder of the Godunov family. In the first half of the 16th century Dmitry Godunov, the uncle of Boris Godunov, also made a contribution there in the form of the central (Western) "fire gilded" doors, where we see images of Aphroditian (the author of the famous "tale" of the Persian Magi prophecy, known in the Russian translation from the 11th century), Homer, Hermes and Menander'.

In the end we should say a few words about Bulgarian Plato. Ancient philosophers are represented in Bulgaria primarily in the Church of the Nativity in Arnabasi and in the Bachkov monastery, which houses perhaps the largest number of ancient sages, some of which (for example, Galen) are hard to find anywhere else (that iconography was examined by Bulgarian researcher Duichev in his book). In the refectory of the Bachkov Monastery (paintings of 1643) Plato is habitually represented next to Sibyl — and again noticeably young, like a youth. Sibyl is depicted with a scroll and the following text: "His Son Christ was born of the Virgin Mary; I believe in Him." The text in Plato's hands is "God has always lived and will live without beginning or end." For comparison and context, we mention images of Socrates and Aristotle. Socrates' text is "And his name will gain glory, and he will be honored in all the universe." Aristotle's text is "The light of St. Trinity will shine in all creation, and God will completely destroy the idols created by hand." The images of ancient philosophers are extremely interesting in 17th-century Arnabasi, and above all we note that the ancient philosophers, not only Plato, Aristotle and Socrates, are depicted with haloes as saints here on the Tree of Jesse (Plato and Aristotle are also with their halos in the Serbian church of Our Lady of Ljevis). Plato here is already represented as a mature man with a coffin on his head surrounded by the halo. Thus, the visual image presents the maximal integration of the great ancient Greek philosopher into Orthodox Christianity. Let us look again at Plato with his scroll and usual text "God has always lived and will live without beginning or end." Sibyl's text is quite interesting: "And he

\footnotetext{
${ }^{1}$ Now this door is in the Ipatiev Monastery museum, where numerous gifts of Godunovs and other families are exhibited. Photos of the doors were made by D. Yu. Dorofeev with the permission of the pilgrimage department of the Ipatiev Monastery and, together with paintings of the cathedral, are presented on the site of the project dedicated to the iconography of ancient philosophers in Orthodox churches. There you can also find photos of philosophers from other cathedrals and churches of the Orthodox world (https://philosophchurch.wordpress.com).
} 
will be crucified by unbelieving Jews, and blessed are those who listen to him, woe to those who do not listen to him." Thus, we very quickly got to know Plato with the coffin, and the halo of the saint.

It is obvious that the analysis of Plato's image in Antiquity and in medieval Orthodox painting (and in general the image of a man, not only in art, but also in life: their differences also need to be kept in mind and explored) no longer fits the boundaries of the structural-semiotic approach. We want to reveal the greater importance and sovereignty of the visual component of the image, which has its own expediency and is not so much in the relationship of submission with the language, as in a dialogue, although sometimes conflicted. Aesthetics of the human image serves as a basis for it, which can show its productivity in relation to Plato. We have tried to take only the first step in this direction.

\section{REFERENCES}

Barthes, R. (1994) Selected works: Semiotics. Poetics. Moscow: Progress (In Russian).

Brisson, L. (2017) Platon. L'ecrivain qui inventa la philosophie. Paris: Les Editions du Cerf.

Buslayev, F. (1861) Historical essays on Russian folk literature and art. Vol. 1. SaintPetersburg (In Russian).

Bykova, M.V., Pashkevich, M.A. (2020) "Engineering and ecological survey of oilcontaminated soils in industrial areas and efficient way to reduce the negative impact", in: V. Litvinenko, ed. Scientific and Practical Studies of Raw Material Issues- Proceedings of the Russian-German Raw Materials Dialogue: A Collection of Young Scientists Papers and Discussion, 2019. Leiden: CRC Press/Balkem, 135-142 (In Russian with an English abstract).

Chizhevsky, D. I. (1930) "Plato in Ancient Russia", Proceedings of the Russian Historical Society in Prague. Book 2. Prague, 71-81 (In Russian).

Djuric, B. (2006) "Plato, Plutarch, and the Sibyl in the Fresco of the Episcopal Church of the Virgin Ljeviska", J. Burke, V. Betka, R. Scott, eds., Byzantine Narrative Papers in Honour of Roger Scott. Melbourne: Australian Association for Byzantine Studies, 274-289.

Dorofeev, D.Yu. (2019) Human Identity in Plato's "Alcibiades I" (Some Notes on Anthropological Questions in Ancient Greek Philosophy), $\Sigma X O \Lambda H$ (Schole) 13.1, 251-268 (In Russian with an English abstract).

Dorofeev, D. Yu., Savchuk, V. V., Svetlov, R. V. (2019) Iconography of Ancient Philosophers: History and Anthropology of Images. St. Petersburg: PFO (In Russian).

Duichev, I. S. (1978) Ancient Thinkers and Writers in the Old Bulgarian Painting. Sofia: Septemvri (In Bulgarian).

Festugiere, A.-J. (2009) Contemplation and Contemplative Life According to Plato. SaintPetersburg: Nauka (In Russian). 
Goncharko, O. Y., Goncharko, D. N. (2017) “A Byzantine logician's “image” within the second iconoclastic controversy. Nikephoros of Constantinople", Scrinium 13.1, 291308 .

Goncharko, O. Y., Goncharko, D. N. (2019) "A Byzantine logician's "image" within the second iconoclastic controversy. Theodore the Studite", Scrinium 15.1, 163-177.

Gromov, M. N. (2010) Images of philosophers in ancient Russia. Moscow: IF RAN (In Russian).

Hafner, G. (1984) Outstanding Portraits of Antiquity. 337 portraits in Image and Word. Moscow: Progress (In Russian).

Kantor, M. K. (2020) "Justification of Iconosophy". https://story.ru/istoriiznamenitostej/istoriya-iskusstv/maksim-kantor-obosnovanie-ikonosofii-/ (10.09.2020) (In Russian).

Kazakova, N. A. (1961) "Prophecies of Hellenic Sages" and their images in Russian painting of the 16th and 17th centuries", Proceedings of the Department of Old Russian Literature of the Institute of Russian Literature. Vol. 17. Leningrad / Moscow: Nauka, 358-368 (In Russian).

Litvinenko, V. S. (2020a) "Digital Economy as a Factor in the Technological Development of the Mineral Sector", Natural Resources Research 29, 1521-1541.

Litvinenko, V. S. (2020b) "The Role of Hydrocarbons in the Global Energy Agenda: The Focus on Liquefied Natural Gas", Resources 5.9, 59-91.

Miller, S. G. (2009) The Berkeley Plato. From Neglected Relic to Ancient Treasure. Berkeley / Los Angeles / London.

Miroshnichenko, E. I. (2012) "Plato and Platonism in Ancient Russian Literature", Vestnik NSU. A series of philosophy. Vol.1o. Issue 1, 129-136 (In Russian with an English abstract).

Muravyov, A. N. (1990) Travels to Russian Holy Places, Moscow, (reprint edition 1846) (In Russian).

Okunev, N. L. (1936) "Orillia. Monument of Serbian Art of the 13th Century", Seminary Condacovianum 8, 221-258.(In Russian).

Ponomarenko, T.V., Volnik, R., Marinina, O.A. (2016) "Corporate Social Responsibility of the Coal Industry (practice of Russian and European companies)", Journal of Mining Institute 222, 882-891 (In Russian with an English abstract).

Premerstein, A. Von (1926) "Griechisch-heidnische Weise als Verkünder christlicher Lehre in Handschriften und Kirchenmalereien", Festschrift der Nationalbibliothek in Wien, hrsg. zur Feier des 20o jahrigen Bestehens des Gahaudes. Wien, 647-666.

Rassadina, S. A. (2017) "Mining Province: The Discourse of Memory and Regional Identity", Journal of Mining Institute 227, 603-607 (In Russian with an English abstract).

Reid Heather, L. (2017) "Performing Virtue: Athletic Mimēsis in Platonic Education", Politics and Performance in Western Greece. Fonte Aretusa, 26o-271.

Reid Heather, L. (2016) "Plato the Gymnasiarch", D. Katsonopoulou \& E. Partida, eds.,

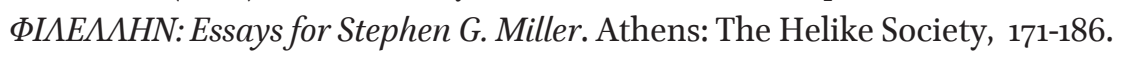


Sergeyev, V. N. (1985) "About the Inscriptions to the Images of "Hellenic Sages"”, Proceedings of the Department of Ancient Russian Literature. Vol. 38. Moscow / Leningrad: Nauka, 1985, 326-331 (In Russian).

Shakhmatov, M. V. (1930) "Plato in Ancient Russia", Proceedings of the Russian Historical Society in Prague. Book 2. Prague, 49-70 (In Russian).

Spetsieris, K. (1963-1964) "Eikones Ellenon filosofon eis Ekklesias", Epistemonike Epeteris

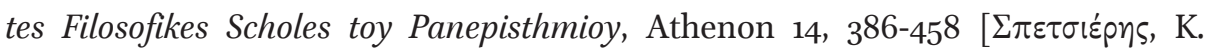

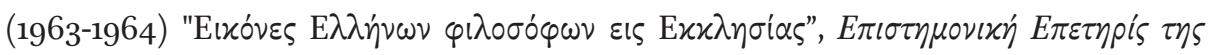

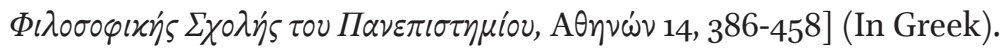

Spidlik, T. (2013) Prayer According to the Legend of the Eastern Church. Moscow: Dar (In Russian).

Svetlov, R. V. (2012) "Socrates in Spartan Camouflage", Logos 6 [9o], 16-28 (In Russian with an English abstract).

Svetlov, R. V. (2015) "Socrates in the Space of Ancient Imagination", $\Sigma X O \Lambda H$ (Schole) 9.1, 169-184 (In Russian with an English abstract).

Tcvetkov, P., Cherepovitsyn, A., Makhovikov, A. (2020) "Economic assessment of heat and power generation from small-scale liquefied natural gas in Russia", Energy Rep. 6, 391-402.

Uspensky, L.A. (2008) Theology of icon of Orthodox church. Moscow (In Russian).

Vakhnin, N. A. (2016) "Man, nature, society - a synergistic dimension", Journal of Mining Institute 221, 761-765 (In Russian with an English abstract).

Voshchinina, A. I. (1974) Roman portrait. The collection of the State Hermitage Museum. Leningrad: Iskusstvo (In Russian).

Yelubayeva M., Mironov A., Kharchenko L., Putecheva O. (2019) "Aspects of the current problems of society in contemporary art", Opcion 23, 547-562 (in Russian).

Zubov, V.P. (1963) Aristotel. Moscow: RAN (In Russian).

Барт, Р. (1994) Избранные работы: Семиотика. Поэтика. Москва: Прогресс.

Буслаев, Ф. (1861) Исторические очерки русской народной словесности и искусства. T. 1. Санкт-Петербург.

Вахнин, Н. А. (2016) «Человек, природа, общество - синергетическое измерение», Записки Горного института 221, 761-765.

Вощинина, А. И. (1974) Римский портрет. Коллекция Государственного Эрмитажа. Ленинград: Искусство.

Громов, М. Н. (2010) Образы философов в Древней Руси. Москва: ИФ РАН.

Дорофеев, Д.Ю. (2019а) «Человеческая идентичность в диалоге Платона Алкивиад I (к вопросу об антропологической проблематике в древнегреческой философии)», $\Sigma Х О \Lambda Н$ (Schole) 13.1, 251-268.

Дорофеев, Д. Ю., Савчук, В. В., Светлов, Р. В. (2019b) Иконография античных философов: история и антропология образов. Санкт-Петербург: ПФО.

Зубов В.П. (1963) Аристотель. Москва:РАН. 
Казакова, Н. А. (1961) «"Пророчества еллинских мудрецов” и их изображения в русской живописи XVI-XVII вв», Труды отдела древнерусской литературы института русской литературы. T. XVII. Москва: Наука, 358-368.

Кантор, М. К. (2020) Обоснование иконософии. https://story.ru/istoriiznamenitostej/istoriya-iskusstv/maksim-kantor-obosnovanie-ikonosofii-/ последнее обращение (10.09.2020).

Мирошниченко, Е.И. (2012) «Платон и платонизм в древнерусской литературе», Вестник НГУ. Серия философия 10.1, 129-136.

Муравьев, А. Н. (1990) Путешествия по святьм местам русским. Москва (репринтное издание 1846 г.)

Окунев, Н. Л. (1936) «Арилье. Памятник сербского искусства 13 века», Семинариум Кондаковианум, VIII, 221-258.

Пономаренко, Т. В., Вольник, Р., Маринина, О. А. (2016) «Корпоративная социальная ответственность угольной отрасли (практика российских и европейских компаний)», Записки Горного института 222, 882-891.

Рассадина, С. А. (2017) «Горнопромышленная провинция: дискурс памяти и региональная идентичности», Записки Горного института 227, 6о3-6о7.

Сергеев, В.Н. (1985) «О надписях к изображениям “еллинских мудрецов”», Труды отдела древнерусской литературы. Т. XXXVIII. Москва / Ленинград, 326-331.

Светлов, Р. В. (2012) «Сократ в спартанском камуфляже», Логос 6 (9о), 16-28.

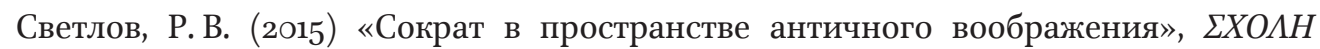
(Schole) 9.1, 169-184.

Успенский, Л.А. (2008) Богословие иконы православной церкви. Москва.

Фестюжьер, А-Ж. (2019) Созериание и созериательная жизнь по Платону. СанктПетербург: Наука.

Хафнер, Г. (1984) Выдающиеся портреты античности. 337 портретов в образе и слове. Москва: Прогресс.

Чижевский, Д. И. (1930) «Платон в древней Руси», Записки русского исторического общества в Праге. Кн. 2. Прага, 71-81.

Шахматов, М. В. (1930) «Платон в Древней Руси», Записки русского исторического общества в Праге. Кн. 2. Прага, 49-7о.

Шпидлик, Т. (2013) Молитва согласно преданию Восточной церкви. Москва: Дар.

Дуйчев, И. С. (1978) Древноезически мислители и писатели в старата българска живопис. София: Септември. 